\title{
Organization and management of the development of ecological tourism in a circular economy
}

\author{
Oleksii Hutsaliuk ${ }^{1 *}$, Iuliia Bondar ${ }^{2}$, Nataliia Sereda ${ }^{2}$, Oksana Babych ${ }^{3}$, and Inna \\ Shchoholieva ${ }^{2}$ \\ ${ }^{1}$ Private Higher Education Institution «International European University», 42 V Glushkova Ave., \\ 03680, Kyiv, Ukraine \\ ${ }^{2}$ Flight Academy of National Aviation University, 1 Dobrovolsky Str., 25005, Kropyvnytskyi, \\ Ukraine \\ ${ }^{3}$ Central Ukrainian Institute of Human Development International University of Human Development \\ «Ukraine», 8 Peoples Friendship Square, 25015, Kropyvnytskyi, Ukraine
}

\begin{abstract}
In the modern world, the question of the interaction of society and nature is one of the most acute problems among those facing humanity. Today, rapid economic development is causing a significant increase in the use and, consequently, depletion of natural resources. This necessitates the search for a new economic model that could break the link between economic growth and the depletion of natural resources. The study substantiates the theoretical aspects of eco-tourism as an important component of the strategy of sustainable development of tourism in Ukraine. The priority directions of sustainable development of tourism in the context of modernization of economic activity of Ukraine are outlined. The main directions of greening of the tourist sphere are considered. The main functions and principles of eco-tourism are formed and the relevance of the research and the need to develop prospects for the development of eco-tourism in Ukraine are substantiated. The concept of circular economy is a new economic model that manages the development of ecotourism, which allows to resolve the growing contradiction between the need to meet the growing needs of tourists and the limited number of natural, social, economic resources of host destinations in a deteriorating environment.
\end{abstract}

\section{Introduction}

The rapid development of human civilization, population growth and needs is also accompanied by increasing use of natural resources. Depletion of natural resources is one of the largest global problems. The search for ways to solve this problem leads to the creation of a global model in which waste production will be minimized. An alternative to creating such a business model could be a circular economy, which aims to break the link between economic growth and increased consumption of natural resources.

\footnotetext{
*Corresponding author: alex-g.88@ukr.net
} 
Given the critical environmental situation in the world, which is getting worse every year, it is advisable to develop mechanisms to encourage the population to rational (conscious, responsible) consumption and production. Today, the market not only meets the needs of the population in goods and services, but also forms such needs by offering new or modified products of production, the consumer value of which is not always high [1]. This practice causes irrational exploitation of natural resources and generation of large amounts of waste.

A new paradigm of development and conservation of natural resources, their ecological use can be a model of circular economy based on the principles of sustainable development, the main tools of which will be ecological innovations (eco-innovations) and «green» technologies, is environmentally friendly technologies. All these factors indicate the need to find a model that will aim to preserve natural resources and improve the environmental situation, so the organization and management of eco-tourism in a circular economy becomes relevant.

An important area of economic development of Ukraine is the tourism industry, which contributes to employment growth, intensification of investment processes, improving the country's image and is a significant source of income. The tourism industry as a multilateral phenomenon combines economic, social, environmental and cultural aspects. The integration of world economic processes and the use of the latest technological and logistics solutions affect the development of the tourism sector of Ukraine.

The tourism industry has a huge potential for sustainable development, works closely with other sectors of the economy, is one of the most promising, dynamic and profitable in the world economy [2].

Every year the importance of the tourism industry is constantly growing, and consequently the burden on the environment.

Management and administration of the tourism industry at the current stage of economic transformation in Ukraine requires the search for non-traditional approaches and new views, including: improving the management of the tourism industry, creating new methods of administration, economic policy for various categories of tourism enterprises, determining their development strategies.

The implementation of environmental safety policy is of particular importance for Ukraine, so the development of a strategy for managing its development requires the adaptation of national norms and safety requirements to European standards. This requires a combination of positive changes gained by the domestic and international community in the field of theoretical, methodological, practical foundations of natural resources, optimizing the functioning of the ecological and economic system, preserving the quality of the environment in the context of ecologically safe spatial development of tourism. In particular, ecological tourism is one of the five main strategic directions of development of the tourism industry, which is why the study of trends in sustainable development of ecotourism in Ukraine is becoming important and relevant.

Scientific publications, which show the analysis of scientific and information sources, are devoted to the problems of development and management of ecological tourism within the protected areas.

Most of them describe and characterize mainly natural and historical and cultural resources of the territories. In domestic and foreign sources, recently, the number of publications on the development of eco-tourism is growing. Studies of various aspects of eco-tourism development are contained in the works of T. V Kalaitan, V. Stybel [3], M. Malska [4], M. Rutinsky [5] and others. 


\section{Methods}

The purpose of the study is to develop conceptual provisions, practical recommendations and management for the prospects of eco-tourism as an important component of the strategy of sustainable development of Ukraine.

To solve this goal, general scientific and special research methods were used: analysis and synthesis - in the study of the basic functions and principles of eco-tourism; analytical - for the collection, generalization and processing of scientific information on the state of development of eco-tourism in Ukraine; statistical - in order to comparatively assess the trends of eco-tourism in Ukraine; generalization - to formulate conclusions based on research results.

\section{Results and discussion}

The history of the origin, formation and development of tourism has been observed since ancient times. Man discovered more and more new territories, inhabited them and cultivated them. Later, with the development of trade, economic relations between countries required more reliable and detailed information about their countries, populations, customs, traditions. One of the first were merchant travelers who collected such information, because their trips were systematic.

Pilgrimage, which was quite common in ancient times and does not lose its relevance today, has made a significant contribution to the development of travel and the acquisition of knowledge about new countries. Despite the different purpose of all travel, they undoubtedly expanded the geographical knowledge of man, created the conditions for great discoveries aimed at finding wealth, establishing new trade relations and trade relations between countries. With the development of transport infrastructure, many people have the need and opportunity to visit new territories, get acquainted with the customs and life of other peoples. This led to a special form of travel - tourism. The intensification of economic, cultural and cultural ties has significantly increased not only the movement of the population, but also contributed to the construction of roads, hotels, catering establishments, recreation and treatment areas.

Scientific and technological progress has actively contributed to the development of tourism. After all, with the advent of new modes of transport it became much easier to travel, people got to their destination faster. Thus, the development of the tourism industry contributes to increasing budget revenues, creating new jobs, infrastructure development and development of the tertiary sector of the economy, protection and reconstruction of existing historical and cultural monuments, nature protection, etc. $[4,6]$.

Analysis of the historical basis of the tourism industry makes it possible to identify sustainable tourism development as one that is focused on the long term, in the process of such development it is possible to achieve balance in economic, environmental, sociocultural development goals taking into account the interests of all stakeholders. destinations, local population), based on the rational use of tourism potential and multilateral partnership. Adherence to the principles of sustainable tourism development ensures the reduction of the negative consequences of tourism and the achievement of the most rational use of the positive economic effects of tourism activities.

Under the auspices of the World Tourism Organization (UNWTO) in 1996, the key principles of the concept of sustainable tourism development in the XXI century were identified, which were later supplemented by the World Tourism and Travel Council 
(WTTC) and the World Wildlife Fund (WWF). In general, the following principles of the concept of sustainable tourism and ways to implement them can be identified:

- careful use of resources;

- reducing the level of excessive harmful emissions;

- preservation and development of natural and cultural heritage;

- strategic planning of tourism development;

- promoting the development of tourism that supports the economy;

- involvement of local communities;

- staff training;

- tourism marketing;

- systematic and permanent monitoring of the industry [7].

Environmental protection and natural resources require institutional and functional modernization of the management system on the basis of sustainable development by reorienting the management paradigm in the economy of territorial entities, which are manifested in changing the structure of socio-economic system, adding new structural elements, finding new qualities and characteristics. From the point of view of ecology, sustainable tourism is to strengthen the efforts made to protect the environment, as well as the introduction of practical experience in this area.

Sociology identifies sustainable tourism as an attempt to focus more and more on getting to know the local population, which will help to understand local customs, traditions and values of the country. In this regard, tourists should: be interested, but careful with the natural environment; choose accommodation that meets the criteria of sustainability; respect the lifestyle of local communities, their culture, language, customs. Thus, sustainable tourism is considered a form of tourism that promotes long-term resource management to meet economic and social needs, maintain cultural integrity and characteristic environmental processes [8].

The International Organization for Ecological Tourism (IOET) in 1990 gave the following definition «ecological tourism is a responsible trip to natural areas that promotes nature protection and improves the well-being of the local population» [9].

Sustainable development of tourism, of course, contributes to the economic development of any state as a whole. But its achievement requires the creation of certain conditions, first of all, ensuring the ecological attitude to the environment.

In recent years, the tourism industry in Ukraine is developing rapidly, which has led to the recognition of tourism as one of the priority areas of socio-economic development [9]. However, the development of tourism has led to a negative impact on the environment. That is why recently many scientists in the world began to pay attention to the problems of sustainable development of eco-tourism.

Finland, Iceland, Sweden, Norway, Switzerland, Luxembourg, Denmark, Canada, Ireland and Australia are among the ten countries in the world that have the best positions in the sustainable development index. Today's conditions characterize the economy of Ukraine according to the index of sustainable development as one that requires intensification of innovation and investment development of all sectors of the economy [2].

The main idea of ecological tourism is first of all care for the environment, which is used for tourist purposes. Eco-tourism helps to minimize the harmful effects of tourism on the environment, contributes to the protection of natural, cultural and historical values, rural areas, which should serve humanity [3].

The analysis of literature sources allows to allocate such principles and functions of ecological tourism in the conditions of sustainable development which are shown in Figure1. The EU has developed the Europe 2020 Development Strategy [9], which is based on the principles of sustainable development. Its priorities include energy efficiency, rational use of resources, prevention of environmental pollution. 


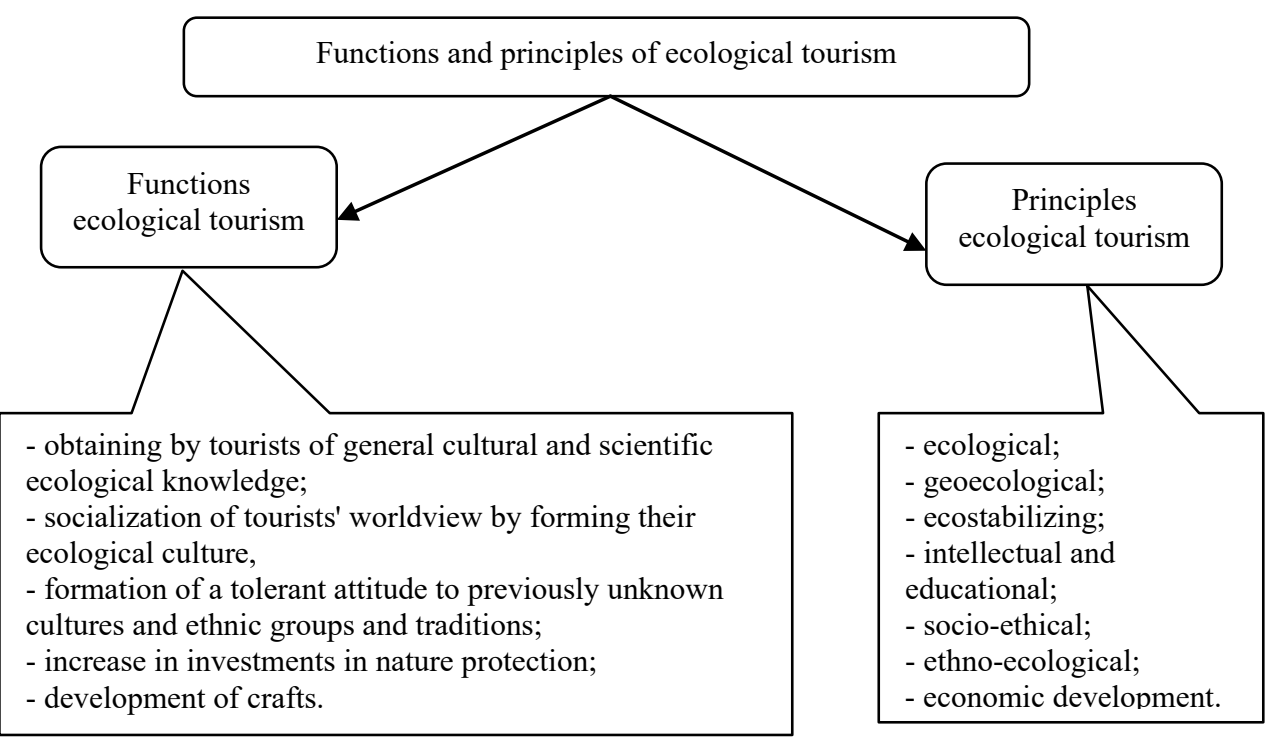

Fig. 1. Basic functions and principles of ecological tourism.

Over the last 20 years, the Council of the EU and the European Commission have adopted more than 200 directives, regulations and regulations relating to the environment. In the process of implementing the Europe 2020 strategy, EU institutions continue to develop and improve European law, combining environmental standards with voluntary instruments inherent in the circular economy model as a basis for the development of sustainable consumption and production. The main trends in the greening of the tourism sector can be seen in Table 1.

Table 1. Directions of greening of the tourism sector.

\begin{tabular}{|l|l|}
\hline \multicolumn{1}{|c|}{ Directions } & \multicolumn{1}{c|}{ Components of tourist areas } \\
\hline Planning of tourist activity & $\begin{array}{l}\text { - regulation of the number of visitors, } \\
\text { - restrictions on visits to particularly valuable sites and ecosystems, } \\
\text { - creation of additional attractions: museums, ecological farms, visit } \\
\text { centers, thematic exhibitions and expositions. }\end{array}$ \\
\hline $\begin{array}{l}\text { Use of environmentally } \\
\text { friendly modes of transport }\end{array}$ & $\begin{array}{l}\text { - cars with electric motors or solar panels, } \\
\text { - alternative means of transportation (bicycles, boats, horse-drawn } \\
\text { carriages, pack animals). }\end{array}$ \\
\hline $\begin{array}{l}\text { Establishing strict } \\
\text { environmental requirements } \\
\text { for mobile vehicles }\end{array}$ & - «Green car». \\
\hline $\begin{array}{l}\text { Development of tourist } \\
\text { infrastructure }\end{array}$ & $\begin{array}{l}\text { - strict control over the use of technologies to save electricity, } \\
\text { - establishment of control over observance of requirements of } \\
\text { arrangement of tourist routes, } \\
\text { - compliance with anti-erosion requirements when laying roads, } \\
\text { - saving space. }\end{array}$ \\
\hline $\begin{array}{l}\text { Use of alternative energy } \\
\text { sources }\end{array}$ & $\begin{array}{l}\text { - solar, } \\
\text { - wind, } \\
\text { - geothermal. }\end{array}$ \\
\hline $\begin{array}{l}\text { Use of devices to save heat, } \\
\text { water and electricity }\end{array}$ & $\begin{array}{l}\text { - counters, } \\
\text { - individual heating systems, } \\
\text { - heat-insulating building materials, } \\
\text { - individual heating systems. }\end{array}$ \\
\hline
\end{tabular}


Today, the concept of ecological hotels is extremely popular in the world, which aim to rationally use natural resources, to preserve the health of guests. Such hotels in accordance with European standards must meet the following requirements: have an environmentally friendly heating system, own wastewater treatment plants; to classify all wastes, to use electricity produced with the help of environmentally friendly fuel; to use economic lamps for lighting; prepare food from environmentally friendly products, sometimes even grown in a specially designated area $[5,10]$.

In Ukraine, ecological tourism is carried out in national parks and nature reserves. It is here that the most remarkable natural values are concentrated, the inclusion of which attracts many tourists. According to research, in Ukraine there are at least five of the most interesting top destinations for eco-tourism: Kherson region, Podolsk Tovtry, Carpathians, canyons of Mykolayiv region, Dnieper shores in Cherkasy region (Fig. 2-5) [11].

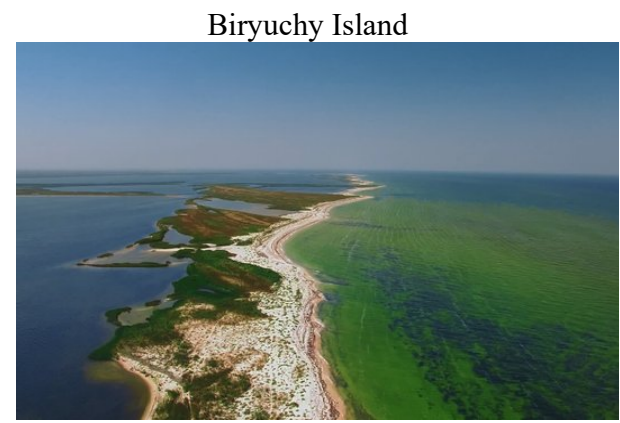

Dzharilgach island

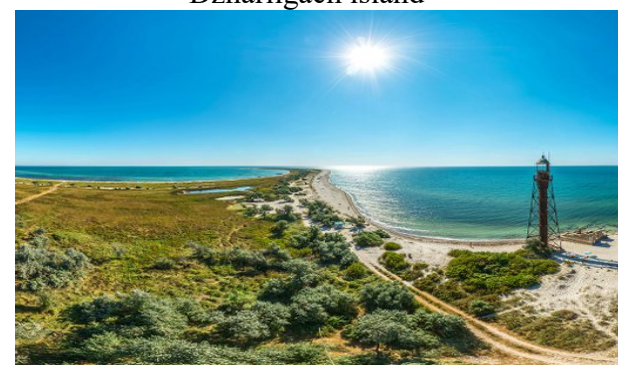

Pink lakes of Kherson region

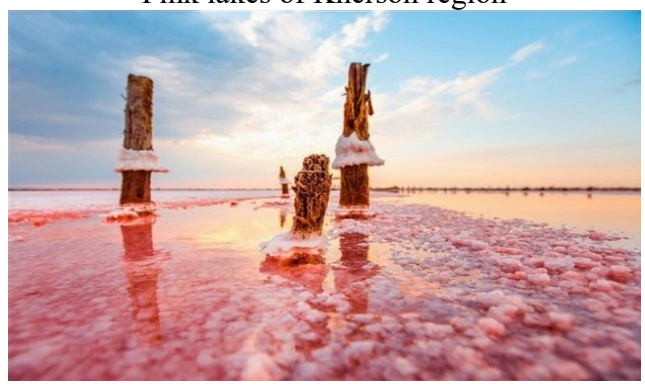

Tendrivska spit

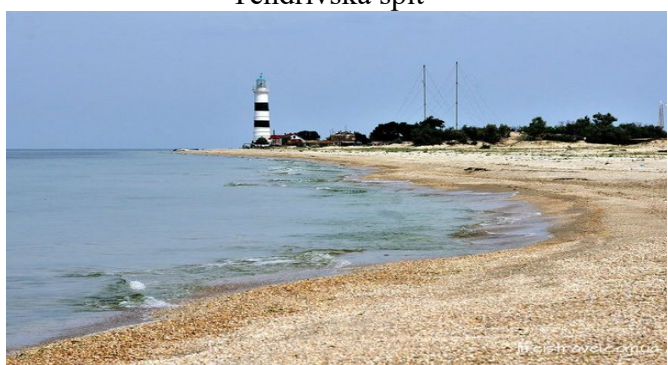

Fig. 2. Top destinations for eco-tourism in Kherson region (Ukraine).

Podolsk Tovtry are the remains of coastal reefs stretched parallel to the ancient coastline

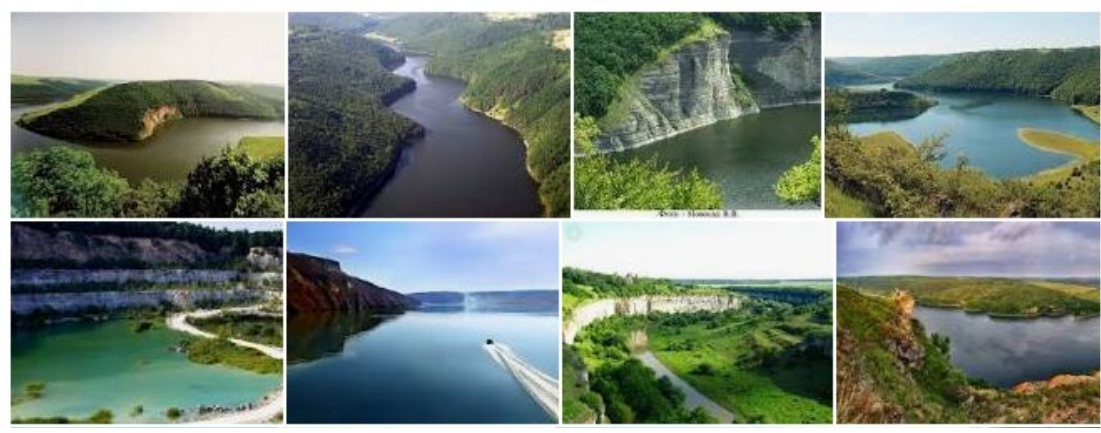

Fig. 3. Top destinations for eco-tourism in Podolsk Tovtry (Ukraine). 
Ukrainian Carpathians are part of the mountain system of Eastern Carpathians in Western Ukraine
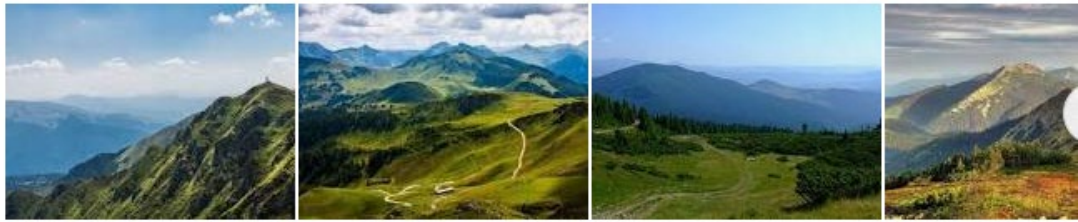

Fig. 4. Top destinations for eco-tourism in Ukrainian Carpathians (Ukraine).

Canyons of the Nikolaev region

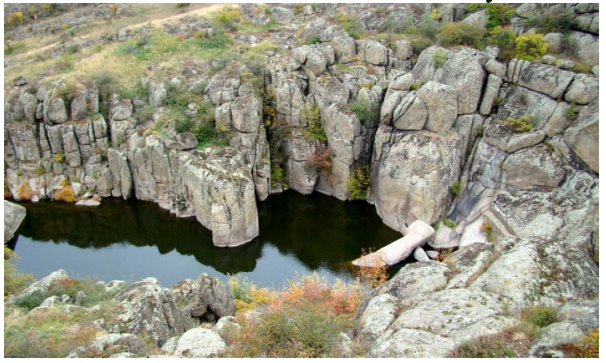

Aktovsky canyon

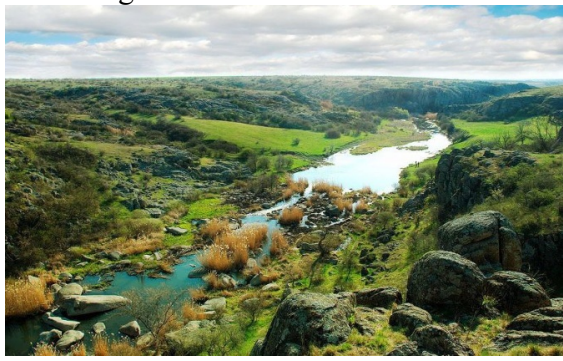

Devil's Canyon

Fig. 5. Top destinations for eco-tourism in Canyons of the Nikolaev region (Ukraine).
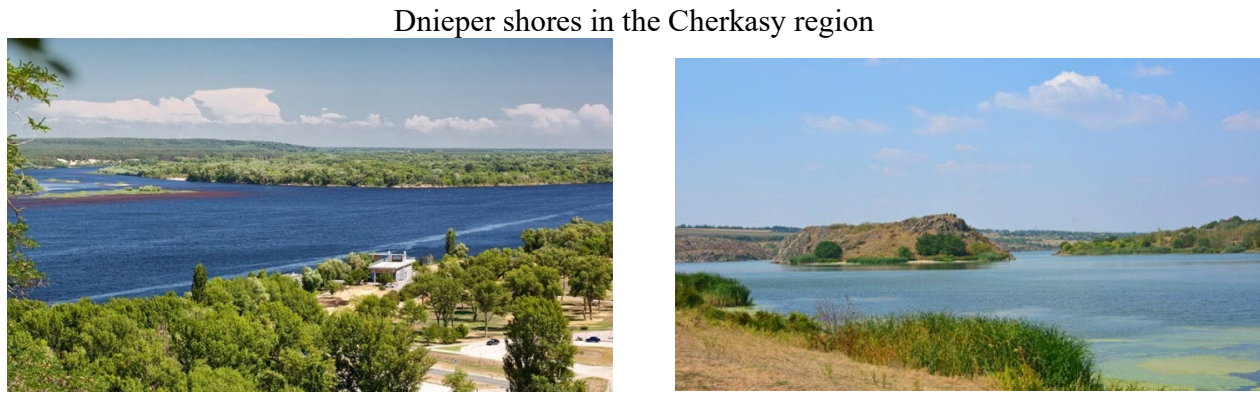

Fig. 5. Top destinations for eco-tourism in Dnieper shores (Ukraine).

In Ukraine, the total area of recreational areas is $12,8 \%$ of the entire territory of the country and is distributed according to the natural features of the regions: Carpathian, Transnistrian, Donetsk-Priazovsky, Polissya, Black Sea [5]. The main basis for the development of ecological tourism in Ukraine is 6737 specially designated areas and objects of the nature reserve, with a total area of over 2,8 million hectares, which exceeds $3,9 \%$ of the total area of the state [3].

In Ukraine, there are 39 reserves and natural and national parks, located on an area of 559, 2 thousand hectares, more details can be seen from Table 2 .

Ecotourism involves recreation in environmentally friendly regions. There are many such regions in Ukraine, which makes the country ecologically attractive for ecotourism enthusiasts. The main center is the Carpathian region, which includes four regions - IvanoFrankivsk, Zakarpattia, Lviv and Chernivtsi, covers an area of 56,6 thousand square meters. $\mathrm{km}$., home to 6,5 million people. The Carpathian region borders Romania, Hungary, Slovakia and Poland. 
Table 2. Types of reserves in Ukraine and their characteristics.

\begin{tabular}{|c|c|c|c|}
\hline № & View of the reserve & The name of the reserve & Characteristics of the reserve \\
\hline 1 & $\begin{array}{lr}\text { Biosphere } & - \\
(137,2 & \text { thousand } \\
\text { hectares }) & \end{array}$ & $\begin{array}{lll}\text { «Askania } & \text { Nova» } & \text { Biosphere } \\
\text { Reserve } & & \end{array}$ & $\begin{array}{l}\text { one of the } 7 \text { natural wonders of } \\
\text { Ukraine, is one of the hundred } \\
\text { most famous protected areas on } \\
\text { the planet ( } 33,3 \text { thousand } \\
\text { hectares, } 500 \text { species of higher } \\
\text { plants, more than } 3,000 \text { species } \\
\text { of animals) }\end{array}$ \\
\hline 2 & & Carpathian Biosphere Reserve & $\begin{array}{l}\text { (total area } 57,880 \text { ha), which is } \\
\text { part of the UNESCO network } \\
\text { of biosphere reserves - has } 64 \\
\text { species of plants and } 72 \text { species } \\
\text { of animals listed in the Red } \\
\text { Book of Ukraine }\end{array}$ \\
\hline 3 & & $\begin{array}{lll}\text { Danube Biosphere } & \text { Reserve } \\
\text { (Odessa region) } & \end{array}$ & $\begin{array}{l}\text { with a total area of } 50,253 \\
\text { hectares ( } 563 \text { species of various } \\
\text { plants, more than } 200 \text { species of } \\
\text { birds, about } 120 \text { species of } \\
\text { waterfowl, } 100 \text { species of fish) }\end{array}$ \\
\hline 4 & & $\begin{array}{l}\text { Black Sea Biosphere Reserve } \\
\text { (Kherson and Mykolaiv region) }\end{array}$ & $\begin{array}{l}\text { with a total area of } 100 \\
\text { hectares: } \\
\text { - about } 700 \text { species of plants, } \\
-309 \text { species of birds, } \\
-83 \text { species of fish. }\end{array}$ \\
\hline 5 & \multicolumn{2}{|c|}{ Nature reserves - 17 (160,1 thousand hectares) } & $\begin{array}{l}\text { Located on the territory of } \\
\text { Ukraine }\end{array}$ \\
\hline 6 & $\begin{array}{l}\text { National } \\
\text { parks - } 18\end{array}$ & Located on the territory of Ukraine & $\begin{array}{l}\text { The total area of } 261,9 \\
\text { thousand hectares; } 45 \text { regional } \\
\text { landscape parks; } 3078 \text { natural } \\
\text { monuments, } 2729 \text { reserves, } 616 \\
\text { botanical, zoological gardens, } \\
\text { arboretums, and parks- } \\
\text { monuments of landscape art, } \\
793 \text { protected tracts }\end{array}$ \\
\hline
\end{tabular}

Source: generalized on the basis of $[3,11]$

In the Carpathian region there are good conditions for tourism development: good geographical location (proximity to the markets of Central and Western Europe; developed transport network, natural resources (mineral waters, mountains, rivers, lakes, waterfalls), historical and cultural heritage, castles and palaces, ancient cities with a rich historical heritage, preserved traditions and original folk art (embroidery, pottery, quilting, Easter painting, carving, weaving, weaving, basketry), a variety of national cuisines (cooking and tasting of local dishes and drinks), smoked, canned berries, vegetables and mushrooms, home-made local pastries), relatively high environmental safety, socio-economic specifics of mountain areas, the possibility of communicating with nature (excursions, hiking, horseback riding, hunting, fishing, sleigh rides or carts, watercraft, photo hunting, cleaning , harvesting flowers, herbs, relaxing in a hammock, on the beach near the pond or in the garden), the possibility of classes sports (tennis, swimming, volleyball, mini-golf, minibasketball, archery, cycling, motorcycles or ATVs) [12-15].

In the Carpathian region there are about 800 sources of mineral water of almost all balneological types. The Carpathians are the most attractive in this region. During the winter holidays, tourists are attracted by skiing, participation in various traditional folk rites and celebrations. 
In summer, holidays in this region are unusual landscapes, spruce forests, clean air, mountain rivers, equestrian tourism, water tourism (rafting), cycling, wine and tasting tourism [16-19]. You can diversify your vacation by picking wild berries and mushrooms, hiking in the mountains and meadows, performances by folk musicians, visiting unique wooden churches and natural monuments, caring for pets, bees, learning folk crafts, sports, fishing, participation life of a peasant family and village.

The most popular centers of green tourism in the Carpathians - Yaremche, Bukovel, Vorokhta, Yabluchnytsia, Yasenya, Tatariv, Verkhovyna, Slavske, Kosiv, Rakhiv and others. The protected hilly area - Roztocze in the Lviv region attracts tourists with architectural monuments, famous places, picturesque rocks and grottoes. Roztocze is located in the cross-border region of Ukraine and Poland and is of great ecological importance not only for the two neighboring countries, but also for Central and Eastern Europe. Within Ukraine, its length is $75 \mathrm{~km}$ and width varies from $15-17 \mathrm{~km}$ (Rava-Ruska Nemyriv district) to $40 \mathrm{~km}$ (Zhovkva - Novoyavorivsk district). The region is extremely valuable in terms of biological and landscape diversity. Well-preserved nature, picturesque landscapes, cascades of lakes, favorable microclimate, good communication contributed to the development of Roztocze as a popular recreational area.

Potential opportunities for the development of ecotourism exist in the Skole district, which has architectural monuments of local and national importance (ancient wooden churches, chapels and bell towers); the largest ski center in Ukraine is the town of Slavske; more than 35 protected sites, including Uritsky rocks, the remains of the ancient Russian fortress «Tustan» - XI-XII centuries; waterfalls near the village Dubna and village Korchin, mineral water deposits. Ski slopes are laid on the town of Vysokyi Verkh (Pisana) (1241 $\mathrm{m})$, Trostyan $(1235 \mathrm{~m})$, Menchil $(1072 \mathrm{~m})$, Pohar $(857 \mathrm{~m})$. Now in Tysovka there are also freestyle competitions and demonstration performances of snowboarders.

Skole - one of the historical centers of Boykivshchyna, included in the List of historical settlements of Ukraine, is a good starting point for a number of tourist routes - on Mount Parashka, in the village Tykhlyu, on the Zelemin ridge and Mount Magura. On the right bank of the Resistance, across the road bridge, there is a recreational zone «Pavliv Potok», which includes two camps («Hutsulka» and «Prolisok»), a lake with beaches, relict spruce forests, a source of «iron» water, a well «Oksana», with water type «Naftusya» (hydrogen sulfide sources), there are also soda, iodine-bromo-ferrous, carbonated mineral and mineral waters without specific components.

Unlike other types of tourism, eco-tourism does not require significant infrastructure development costs. However, the development of ecological tourism requires the provision of protection, integrated use of resources, environmental safety and availability of recreational resources. It should be noted that with proper organization and skillful management of eco-tourism it is possible to maintain a balance of environmental, social and economic interests.

Such a management tool in the field of eco-tourism as the formation of a network of urban tourist information centers, which will enhance sightseeing and increase the tourist attractiveness of the country, is becoming increasingly important and will also increase income [20-23].

Ecological tourism in the conditions of sustainable development of economic activity of Ukraine becomes one of the most perspective types, as it provides change of impressions and constant contact with the nature in combination with low financial expenses, namely, cognitive rounds (acquaintance with cultural-historical, ethnographic, natural objects). projects), entertainment tours (fishing, boat trips, picking: mushrooms, nuts, berries, medicinal plants), wellness tours (green tourism, swimming in ponds, physical labor) [2426]. 


\section{Conclusions}

Thus, the circular economy is a new economic model, which provides for the rational use of natural resources, recycling, efficient energy conservation and more. Therefore, the concept of a circular economy is ecological tourism, which makes it possible to resolve the growing contradiction between the need to meet the growing needs of tourists and the limited number of natural, social, economic resources of host destinations in a deteriorating environment.

It should be noted that the main purpose of eco-tourism as a type of tourist activity is to learn about the features of the little-changed natural and traditional cultural landscapes, provided that the landscape diversity is preserved. On the territory of Ukraine there are quite favorable conditions and resources for the development of eco-tourism, but for it to become a priority of national tourism, the basis of its development should be the development of special state, regional and local programs for eco-tourism, as well as conscious attitude of each us to the environment. In the process of introducing decentralization of power, it would be appropriate to give greater powers to regional and local authorities to participate directly in the regulation of eco-tourism activities.

The modern concept of eco-tourism emphasizes the need to preserve natural and cultural heritage, biodiversity and improve the ecological, social and economic condition of the regions visited by eco-tourists. Eco-tourism should become a model for reorganization, greening of the entire tourism industry. Sustainable ecologically balanced tourism should become not only a philosophy, but also a leading management strategy for tourism development in the region.

Comprehensive implementation of the concept of circular economy makes eco-tourism more important every year, allows more efficient and rational use of community resource potential and better solve regional development problems.

Ensuring the model of the circular economy of Ukraine will help increase national competitiveness, minimize the negative effects of external shocks, increase the social and environmental responsibility of entrepreneurship.

\section{References}

1. European Union (2020). The Circularity Gap Reform 2020. https://circulareconomy.europa.eu

2. Baklanova, O., Petrova, M., Koval, V. (2020). Institutional Transmission in Economic Development. Ikonomicheski Izsledvania, 29(1), 68-91.

3. Kalaitan, T. V., Stybel, V. V., Gutyj, B. V., Hrymak, O. Y., Kushnir, L. P., Yaroshevych, N. B., ... \& Kindrat, O. V. (2021). Ecotourism and sustainable development. Prospects for Ukraine. Ukrainian Journal of Ecology, 11(1), 373-383.

4. Malskaya, M.P., \& Khudo V.V. (2012). Tourism business: theory and practice. textbook way. Kyiv: Center for Educational Literature.

5. Rutinsky M.Y., \& Zinko Y.V. (2006). Rural tourism. Kyiv: Knowledge.

6. Ustimenko L.M., Afanasyev I.Y. (2005). History of tourism. Kyiv: Alter-press.

7. UNWTO (2014). International Tourism Results and Prospects for 2014. HQ, Madrid, Spain. https://www.e-unwto.org/doi/pdf/10.18111/9789284417919

8. Global Sustainable Tourism Council (2020). The Partnership for Global Sustainable Tourism Criteria (GSTC Partnership). Global Sustainable Tourism Criteria (GSTC) website. www.sustainabletourismcriteria.org

9. Europe 2020. (2020). A strategy for smart, sustainable and inclusive growth. Brussels, 3/3/2010/ COM (2010).

10. Lyubitseva, O.O. (2004). Market of tourist services (geospatial aspects). Kyiv. 
11. Kifyak, V.F. (2008). Organization of tourism. Teaching. Chernivtsi: Books - XXI.

12. Osipchuk, M.D. (2014). International tourism in the context of modernization of foreign economic activity of Ukraine. Scientific Bulletin of Kherson State University. Series: Economic Sciences, (6), 107-111.

13. Pimenov, V.G. (2018). Development of ecological tourism in Ukraine: basic concepts, problems, current state. Bulletin of the KhDAK, 52, 198-208.

14. Tambovceva, T., Atstaja, D., Tereshina, M., Uvarova, I., \& Livina, A. (2020). Sustainability challenges and drivers of cross-border greenway tourism in rural areas. Sustainability, 12(15), 5927.

15. Hutsaliuk, O., Smutchak, Z., Sytnyk, O., Krasnozhon, N., Puhachenko, O., \& Zarubina, A. (2020). Mass labour migration in the vector of international tourism as a determinant sign of modern globalization. Turismo: Estudos \& Práticas (UERN), Mossoró/RN, Caderno Suplementar, (3).

16. Hutsaliuk, O., Koval, V., Tsimoshynska, O., Koval, M., Skyba, H. (2020). Risk Management of Forming Enterprises Integration Corporate Strategy. TEM Journal, 9(4), 1514-1523. https://doi.org/10.18421/TEM94-26

17. Atstaja, D., Uvarova, I., Kambala, D. K., Alberte, V., Stokmane, K., GegereZetterstroma, A., ... \& Zapletnuka, G. (2020, October). Investments to Develop Business Models and Projects in the Circular Economy. In IOP Conference Series: Earth and Environmental Science (Vol. 578, No. 1, p. 012029). IOP Publishing.

18. Kvasha, S., Pankratova, L., Koval, V., \& Tamošiūniene, R. (2019). Illicit financial flows in export operations with agricultural products. Intelellectual Economics, 13(2), 195-209.

19. Petrova, M., Koval, V., Tepavicharova, M., Zerkal, A., Radchenko, A., \& Bondarchuk, N. (2020). The interaction between the human resources motivation and the commitment to the organization. Journal of Security and Sustainability Issues, 9(3), 897-907. https://doi.org/10.9770/jssi.2020.9.3(15)

20. Shmygol, N., Schiavone, F., Trokhymets, O., Pawliszczy, D., Koval, V., Zavgorodniy, R., Vorfolomeiev A. (2020). Model for assessing and implementing resource-efficient strategy of industry. CEUR Workshop Proceedings, 2713, 277-294.

21. Mikhno, I., Koval, V., Shvets, G., Garmatiuk, O., \& Tamošiūnienė, R. (2021). Green Economy in Sustainable Development and Improvement of Resource Efficiency. Central European Business Review, 10(1), 99-113. https://doi.org/10.18267/j.cebr.252

22. Yeshchenko, M., Koval, V., \& Tsvirko, O. (2019). Economic policy priorities of the income regulation. Espacios, 40 (38), 11.

23. Dankeieva, O., Solomianiuk, N., Strashynska, L., Fiedotova, N., Soloviova, Y., \& Koval, V. (2021). Application of Cognitive Modelling for Operation Improvement of Retail Chain Management System. TEM Journal, 10(1), 358-367. https://doi.org/10.18421/TEM101-45

24. Uvarova, I., Atstaja, D., Grinbergs, U., Petersons, J., Gegere-Zetterstroma, A., \& Kraze, S. (2020). Transition to the circular economy and new circular business modelsan in-depth study of the whey recycling. In IOP Conference Series: Earth and Environmental Science (Vol. 578, No. 1, p. 012019). IOP Publishing.

25. Koval, V., Mikhno, I., Udovychenko, I., Gordiichuk, Ye., \& Kalina, I. (2021). Sustainable Natural Resource Management to Ensure Strategic Environmental Development. TEM Journal (in press).

26. Petrova, M., Dekhtyar, N., Klok, O., \& Loseva, O. (2018). Regional tourism infrastructure development in the state strategies. Problems and Perspectives in Management, 16(4), 259-274. https://doi.org/10.21511/ppm.16(4).2018.22 